9. Harris N.M. MAKING IT NEW: "modernism" in B.E. Baughan's New Zealand poetry: a thesis presented in fulfilment of the requirements for the Degree of Doctor of Philosophy. University of Canterbury, 1992. 263 p.

10. Newton J. Poetry (Story by John Newton, published 22 Oct 2014) / Te Ara - the Encyclopedia of New Zealand. URL: http://www.TeAra.govt.nz/ en/poetry (accessed 14 July 2019).

11. Stead C.K. New Zealand literature. Encyclopedia Britannica. 2020. URL: https://www.britannica.com/art/New-Zealand-literature. (Last accessed: 05.02.2020).

DOI https://doi.org/10.30525/978-9934-26-110-7-39

\title{
IDENTIFICATION OF THE BASIC CONCEPTS (CASE OF THE ANGLO-IRISH WORLDVIEW OF IRELAND)
}

\author{
Polhorodnyk D. V. \\ $P h D$ in Linguistics, \\ Associate Professor at the Department \\ of Foreign Languages for Specific Purposes \\ Zaporizhzhya National University \\ Zaporizhzhya, Ukraine
}

Linguoconceptology is one of the important branches of linguistics due to its aim at the study of the national-cultural part of the units of the mental lexicon - concepts, which are the basic elements of the conceptosphere of the ethnos, the ethnic worldview. While cultural concepts represent the uniqueness of a particular culture and the worldview of its bearers [5, p. 29], each language possesses a set of semantically loaded words that denote components of the worldview, important for a particular culture. It is important to note that every culture contains universal and ethnically determined elements that are actualized in traditions, habits, speech etiquette and are accumulated in the minds of cultural bearers. Thus, the conceptosphere is formed by conceptual universals and unique features, and two categories of concepts are significant and historically constant - key and basic concepts.

Key concepts (key words), according to A. Wierzbicka [4, p. 2], are containers of culture and reflect culture-specific meanings of a situation or object. Basic concepts are not culturally unique. These are universal concepts that integrate stereotyped ideas about time, space, nature, human beings, human's place in the universe, and relationships between humans. Pime- 
nova M. V. [7, p. 129] believes that the basic concepts are the foundation of language and the whole worldview.

In situations of ethnic contacts, basic concepts become even more important because they undergo semantic changes that are not always explicit in the language. They are contained in the minds of cultural bearers and are often latent.

Identification of basic concepts of culture is carried out according to severalcriteria that have been developed and tested by various researchers (A. Wierzbicka, V. I. Karasik, Yu. S. Stepanov).

Important criteria for identifying a concept include the presence of a name [6, p. 56]; the constant nature of the concept [8, p. 84]; cultural elaboration [4, p. 1-31]; frequency of appeal to the concept; socio-cultural value of the concept [6, p. 56]. By extrapolating these criteria, we establish the basic concepts of English-speaking culture in Ireland - Ireland and Irishman.

The presence of the name in the concept, the formation and stability of the core indicate the completion of the process of conceptualization of the concept [6, p. 56]. The names of such basic concepts as Ireland and Irishman are Eire, the Emerald Isle, the Republic of Ireland for Ireland; Eireannach, Irelander, Irisher for Irishman.

The constant nature of the concept means that this concept exists constantly or for a long time. That is, the basic concept should be a "permanent principle of culture" [8, p. 84]. The constancy of the concepts Ireland and Irishman is confirmed by the archaic nature of their names, which function in English: the nominations Ireland and Irishman are formed by a composition of etymologically different components in the twelfth century - Ire- $(<$ Eire $)+-$ land (< lond, «ground, soil»); Ire- $(<$ Eire $)+-$ man (< mann, «human being, person») [3].

The relevance of the principle of cultural elaboration of a concept is illustrated by A. Wierzbicka [4, pp.1-31]; a concept should be accompanied by culture-specific associations. For example, synonymous verbalizations of the concept of Ireland embody information about the nature of the island (the Emerald Isle, Wolfland) the culture and the mythology of the Irish (Eire «the ancestral goddess of the Irish people»), the country's history and administrative background (the Twenty-Six Counties). As for the concept Irishman, it contains information about ethnicity (Gael, Celt), typical names of men (paddy, mick, mickey), religious (Catholic) or political (fenians) affiliation.

An auxiliary indicator to the principle of cultural elaboration is the criterion of frequency, i.e. culturally important concepts are referred to more often. The disadvantage of this criterion is that the frequency will only be a 
representative indicator when the frequency of use of equivalents in other languages is very different. The results of the study will always depend on the volume of the corpus and the variety of texts involved in the analysis.

The socio-cultural value of the concept is manifested in the speech behavior of the bearers of the English-speaking worldview in Ireland through statements with an evaluative component, e.g. «Ireland had been the source of my inspiration» [2], "I am under impression that Irish men are very good people» [1]. The basis of evaluation is a value-oriented position, which is inherent in the subject of evaluation, their beliefs, ideas about the ideals, standards.

Thus, the concepts Ireland and Irishman are the basic concepts of the Anglo-Irish worldview of Ireland, and their verbalizers should be classified as those through which the ethnic group self-identifies. Basic concepts reflect the peculiarities of perception, thinking, assessment of reality by native English speakers in Ireland.

\section{References:}

1. From Ukraine with love. Independentie. URL: https://www.independent.ie/style/sex-relationships/from-ukraine-withlove-26681780.html (access date 30.06.2021).

2. O'Brien E. Country Girl. London: Faber \& Faber, 2012. 352 p. URL: https://books.google.com.ua/books?id=SYtbGphuCLwC_(access date 30.06.2021).

3. Online Etymology Dictionary. URL: https://www.etymonline.com/ (access date 30.06.2021).

4. Wierzbicka A. Understanding Cultures through Their Key Words (English, Russian, Polish, German, and Japanese). New York, Oxford: Oxford University Press, 1997. 328 p.

5. Карасик В. И. Зеркальный концепт «Простота». Новое в когнитивной лингвистике. Кемерово: КемГУ, 2006. Вып. № 8. С. 26-41.

6. Карасик В. И. Концепты-релятивы. Язык, сознание, коммуникация. Москва: МАКС Пресс, 2005. Вып. 30. С. 95-108.

7. Пименова М. В. Типы концептов и этапы концептуального исследования. Вестник Кемеровского государственного университета. Кемерово: КемГУ, 2013. С. 127-131

8. Степанов Ю. С. Константы. Словарь русской культуры. Опыт исследования. Москва: Языки русской культуры, 1997. 824 с. 